九州大学学術情報リポジトリ

Kyushu University Institutional Repository

New Oriental and Australian Conoderinae, with Taxonomic Notes on the Tribe Othippiini (Coleoptera: Curculionidae)

Kojima, Hiroaki

The Kyushu University Museum, Kyushu University

Lyal, Christopher H. C.

The Kyushu University Museum, Kyushu University

https://doi.org/10.5109/2666

出版情報: ESAKIA. 42, pp. 161-174，2002-03-31. Entomological Laboratory， Faculty of Agriculture, Kyushu University

バージョン：

権利関係 : 


\title{
New Oriental and Australian Conoderimae, with Taxomomic Notes on the Tribe Othippiini (Coleoptera: Curculionidae)
}

\author{
Hiroaki KaJIMA \\ The Kyushu University Museum, Kyushu University, \\ Fukuoka, 812-8581 Japan \\ and \\ Christopher H. C. LYAL \\ Department of Entomology, The Natural History Museum, \\ London, SW7 5BD, United Kingdom
}

\begin{abstract}
Two new genera of the subfamily Conoderinae (Zygopinae auctt) are established from the Oriental and Austral Regions under the names of Brimoides gen. mov. and Abrimoides gen. mov. Brimoides includes $B$. morimoto sp. mov., B. ceylonensis sp. mov. and B. exilis (Pascoe), comb. nov. from Lobotrachelus, with some unnamed species. Abrimoides is erected for Metetra esakii Morimoto. These genera are tentatively assigned in the tribe Othippiini Morimoto, although the monophyly of this tribe is now under investigation. Taxonomic notes on the Othippiini, a key to genera and biological information are provided.

Key words: Taxonomy, Curculionidae, Conoderinae, Othippiini, new genera
\end{abstract}

\section{Introduction}

The subfamily Conoderinae Schoenherr, until recently known as Zygopinae Lacordaire (Alonso-Zarazaga \& Lyal, 1999), is one of the largest subfamilies of the weevils, including more than 200 genera and at least 1500 species. The beetles are very abundant in the tropics and are often found on dead or fallen woods or on leaves. They are known to develop in dead wood, leaf petioles, as leaf miner or in seeds. The adults are characterized by their large eyes, which occupy most of the head and, in some groups, by their very 
quick movements similar to certain flies (Hespenheide, 1973). Fighting for females has also been observed in some species (Lyal, 1986), and some of them have a pair of long thoracic spines in males. These are probably developed for the purpose of intra-specific contest as is known in other horned beetles, particularly in the Curculionidae: Baridinae, which sometimes have similar structures (Eberhard \& Garcia-C., 2000). Their unique morphological and behavioural features have fascinated weevil systematists, and taxonomic studies have also been conducted from the early days of weevil systematics (e.g. Pascoe, 1871, 1871a; Heller, 1894, 1894a, 1895). However, their taxonomy is still controversial.

We found two unknown taxa from the Oriental and Australian regions during the course of our study on the Old World Conoderinae. Both are easily confused with several other taxa during routine sorting unless careful attention is paid. They superficially resemble the genus Othippia Pascoe (tribe Othippiini Morimoto) and the genus Lobotrachelus Schoenherr (tribe Lobotrachelini Lacordaire) in having a rhomboidal body with scaly or hairy pattern, and the rostrum capable of being retracted between the pro- and mesocoxae. However, they seem to be most closely related to the previously poorly known Othippiine genus Brimoda Pascoe.

The first new genus comprises species closely resembling small species of Othippia. It is established for undescribed species from Taiwan and Sri Lanka and an Australian species previously incorrectly assigned to Lobotrachelus. Two further species from the Philippines and Malaysia (Sabah), are also included but not described, due to a lack of sufficient material.

The second genus is described for a species from Japan and Taiwan, Metetra esakii Morimoto. Metetra Pascoe is placed in the tribe Lobotrachelini, and is very similar to Lobotrachelus, in having a developed scutellar lobe of the pronotum which covers the scutellum. However, while $M$. esakii has a rhomboidal body form as well as glossy integument very similar to species of Lobotrachelini, it differs in the lack of a developed scutellar lobe and in the morphology of structures such as the eyes and legs. The species is much more closely related to the other new genus described here, and to Brimoda. The significance of the similarity in external features between members of the two tribes is unknown.

Following current treatments (Alonso-Zarazaga \& Lyal, 1999), both new genera are assigned in the tribe Othippiini with Brimoda. However, our studies of Othippiini suggest that it is not monophyletic and that some genera assigned in it should be removed not only from Othippiini but also from Conoderinae. The systematic positions of the new genera described here are discussed below, with some taxonomic notes on the Othippiini and a key to genera.

Specimens used in this study are from the collections of the Entomological Laboratory, Faculty of Agriculture, Kyushu University, Fukuoka (ELKU) and the Natural History 
Museum, London (BMNH). Type material described in this paper will be deposited in both institutes.

\section{Descriptions}

Brimoides Kojima \& Lyal, gen. nov.

Type species: Brimoides morimotoi Kojima \& Lyal, sp. nov.

Small rhomboidal species (length: 1.6-3.4 mm), with scales covering most of dorsal and ventral surfaces, and forming patterns. Integument dull. Eyes large, occupying most of frontal part of head, closely approximate anteriorly and for a much shorter distance posteriorly, but separated by lenticular area on top of head, never concealed by anterior margin of prothorax when rostrum retracted between legs. Rostrum moderately curved, longer than pronotum, with antennal insertion behind middle. Antennae with funicle 7segmented; scape much shorter than funicle. Prothorax subtrapezoidal, widest at base, sides weakly convex in plan, converging anteriorly, apex more or less concave; dorsum with or without very faint median carina on basal half; base with median posteriad lobe, this emarginate posteriorly, and fully exposing scutellum. Scutellum quadrate. Elytra subtriangular, nearly as long as or a little longer than broad, separately rounded at apices, with stria 10 complete. Legs with femora each with small tooth, which is approximately of same size in all pairs; hind femora exceeding elytral apices. Claws small, simple. Prosternum (Fig. 11) with deep canal, bordered by well-developed carinae, these reaching to middle part of coxa; short longitudinal carina behind each procoxa; procoxal separation at least as wide as least width of rostrum. Procoxae and mesocoxae each produced ventrally with tuft of setae, this weaker on mesocoxae than procoxae. Mesosternum usually concave or depressed to receive rostrum (except $B$. exilis), distance between coxae greater than width of coxa. Metendosternite with lateral arms each weakly developed (Fig. 25). Abdomen with ventrites 2-4 subequal in length.

Distribution. Sri Lanka, Taiwan, Philippines, Malaysia (Sabah), Australia (Cape York).

Comments. This genus is very similar to a certain small species of Othippia, but may be close to Brimoda Pascoe, a monotypic genus known from Singapore (discussed below). Brimoides is separable from Brimoda by the following characters: distance between procoxae less than least width of rostrum in Brimoda, thus rostrum not fitting fully between coxae in repose, antennae inserted before middle of rostrum rather than behind middle as in Brimoides, prothorax rounded laterally rather than nearly straight, pronotum widest in middle rather than at base as in Brimoides, elytra longer than broad in Brimoda, as long as or slightly longer than broad in Brimoides, mesosternum never concave or depressed, hind femora not exceeding apices of elytra, ventrite 2 a little longer than 3 or 4 in Brimoda, 

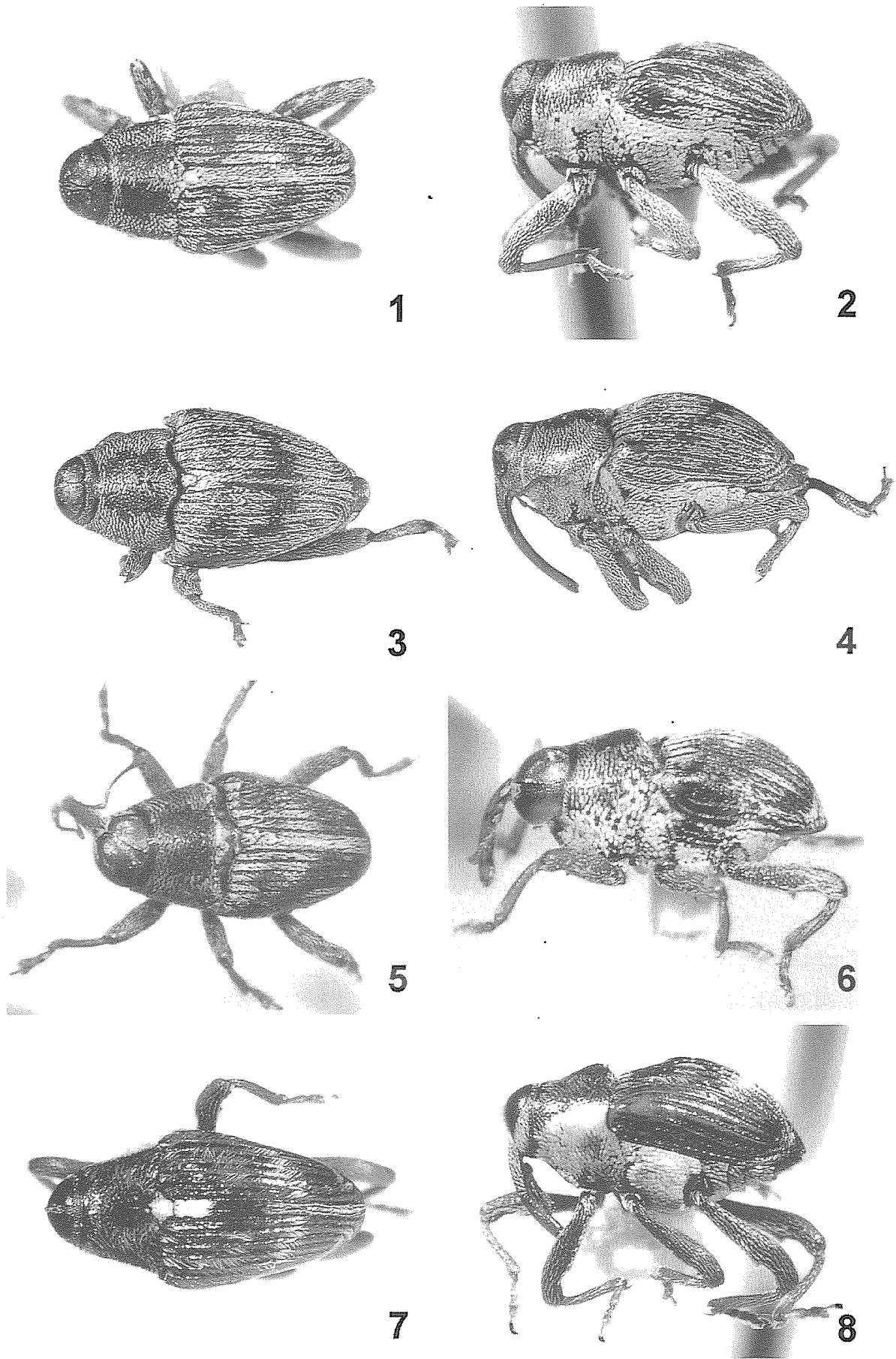

Figs. 1-8. Habitus photographs of Brimoides and Abrimoides spp. -1-2, Brimoides morimotoi sp. nov.; 3-4, B. ceylonensis sp. nov.; 5-6, B. exilis (Pascoe); 7-8, Abrimoides esakii (Morimoto). 
subequal in Brimoides.

Brimoides morimotoi Kojima \& Lyal, sp. nov.

(Figs. 1-2, 9-13, 15-17, 25)

Male. Length: 2.2-2.5 mm. Dark reddish brown, antennae, rostrum, tibiae and tarsi lighter. Integument clothed with yellowish gray, grayish white and dark brown scales, these denser on lateral and ventral parts.

Head clothed with grayish white small scales behind eyes on genae, lenticular area between eyes nearly as wide as apical width of antennal scape. Rostrum 1.2 times as long as pronotum, base and side behind antennal insertion clothed with grayish white scales, which become hair-like anteriorly. Antennae inserted at basal 1/3 of rostrum; scape a little shorter than basal two segments of funicle combined; funicle with basal two segments subequal in length, $3 \mathrm{rd}$ and 4 th subequal, half as long as $2 \mathrm{nd}$, 5th to 7 th subequal, a little shorter than 3rd, each longer than broad.

Prothorax 1.6-1.7 times as broad as long, very weakly curved and narrowing anteriorly; dorsum with median and lateral longitudinal stripes of yellowish gray and grayish white scales (Fig. 1), intervening areas clothed with dark brown scales. Scutellum densely covered with grayish white scales. Elytra 1.1 times as long as broad, grayish white and yellowish brown scales forming basal, median and postmedian bands, which are united on intervals 1 and 6 and lateral areas (Fig. 1), remaining area clothed with dark brown scales. Hind femur with long hairs ventrally between base and tooth (Fig. 13).

Underside clothed with whitish scales except for broad median depression of metasternum and ventrite 1 and weak apical depression of ventrite 5 , where pubescent. Coxal projection weak in fore pair and very weak in middle one. Mesosternum broadly and roundly concave (Fig. 11).

Terminalia as illustrated (Figs. 15-17); aedeagus with long apophysis about twice as long as length of median lobe; endophallus densely spiculate around middle and with long flagellum.

Female. Unknown.

Specimens examined. Holotype male (Type No. 0000, ELKU), Taiwan. Wulai, nr.Taipei, 27.v.1965, (K. Morimoto). Paratypes, 5 specimens, same data as holotype (ELKU and $\mathrm{BMNH}$ ).

Distribution. Taiwan.

Brimoides ceylonensis Kojima \& Lyal, sp. nov.

(Figs. 3-4)

Very similar to $B$. morimotoi, but differs in the following points: lenticular area between eyes very narrow; antennae with 2nd funicle segment shorter than 1st; elytra with humeri 

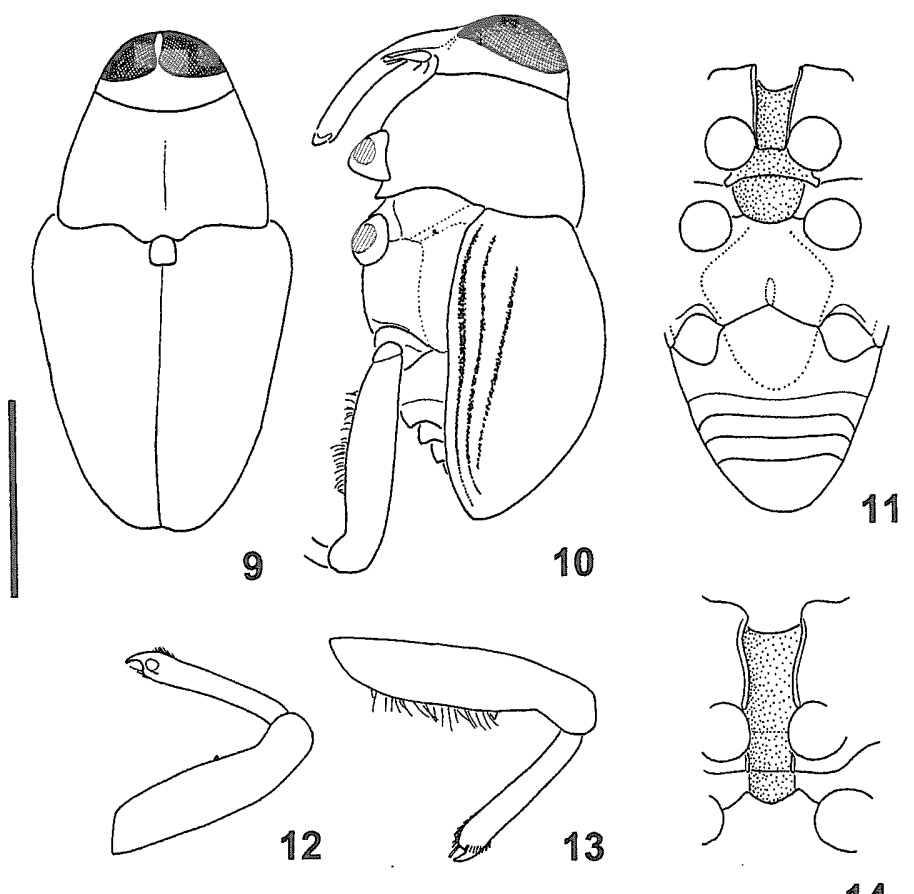

10

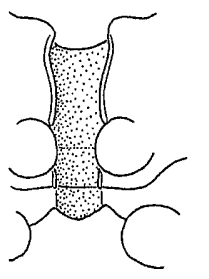

14

Figs. 9-14. Characteristic features of Brimoides and Abrimoides spp., 9. Outline of habitus, dorsal; 10 , outline of habitus, lateral; 11, body, ventral; 12 fore tibia and femur; 13, hind tibia and femur; 14, pectoral canal, ventral. -9-13, Brimoides morimotoi sp. nov.; 14, Abrimoides esakii (Morimoto).

produced anteriorly; hind femora without hairs ventrally between base and tooth in male; mesosternum depressed, but not concaved; metasternum and ventrite 1 weakly depressed in male and not pubescent but scaled, scales denser on ventrite 1 than metasternum. Length: $2.2 \mathrm{~mm}$ (male) or 2.5-3.0 mm (female).

Specimens examined. Holotype female (BMNH), Sri Lamka (Ceylon). Bogawantalawa, 4,900-5,200 ft., 21.iii-4.iv.82 (G.Lewis). Paratypes, 1 female, same locality as holotype, 28.ii-12.iii.82.(G.Lewis; BMNH). 1 male, Sri Lanka (Ceylon), Dikoya, 3,600-4,200 ft., 6.xii.81-16.i.82 (G.Lewis; BMNH); 1 female, 13-16.ii.82 (G.Lewis; BMNH).

Distribution. Sri Lanka.

Brimoides exilis (Pascoe), comb. nov.

(Figs. 5-6)

Lobotrachelus exilis Pascoe, 1885: 290. - Hustache, 1934: 66. 


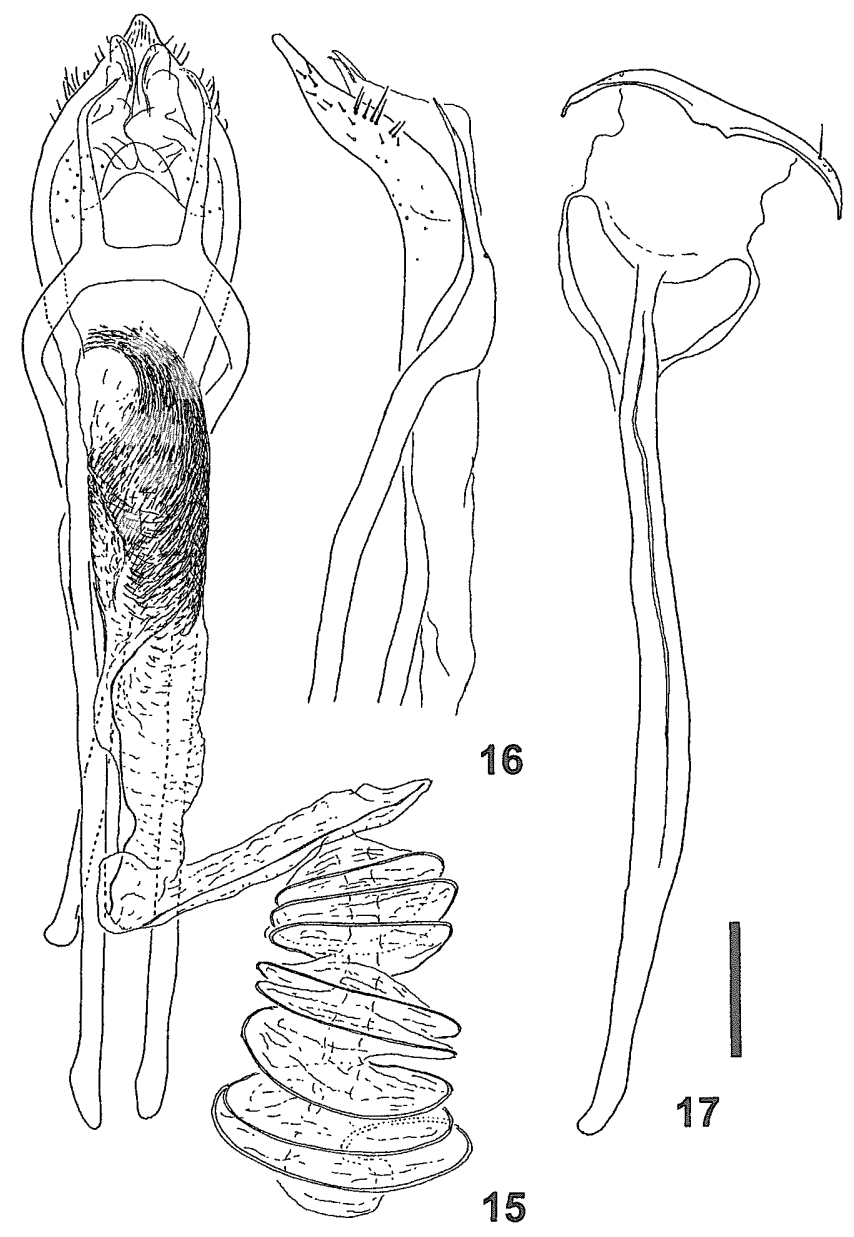

Figs. 15-17. Male genitalia of Brimoides morimotoi sp. nov. - 15, aedeagus, dorsal; 16, aedeagus, lateral; 17, sternite 8 and spiculum gastrale.

Very similar to B. morimotoi and B. ceylonensis, but smaller: $1.6-2.0 \mathrm{~mm}$ in length; antennae with 2nd funicle segment shorter than 1st; lenticular area between eyes wider than apical width of antennal scape; pronotum and elytra with different scale pattern (Figs. 5-6); and mesosternum not depressed and metasternum and ventrite 1 weakly depressed in male.

Lectotype, here designated, with labels: "LECTO-;TYPE" (disc bordered with purple) and "Type" (disc bordered with red) and "Somerset" (green oval, written by Pascoe) and "Lobotrachelus; exilis; Type Pasc" (handwritten, Pascoe) and "Pascoe Coll.; 93-60", (printed) and "Not; Lobotrachelinae; has simple claws; 1951; Det. By E.C. Zimmerman" and "LECTOTYPE; Lobotrachelus; exilis Pascoe; 1885; Kojima \& Lyal 2000" 
(handwritten).

Specimens examined. 2 specimens, Australia: Queensland: Cape York Peninsula, Somerset ( D'Albertis) (Lectotype and Paralectotype, BMNH).

Distribution. Australia (Queensland).

\section{Key to species}

1(2): Antennae with basal two segments subequal in length. Mesosternum evidently roundly concave. Metasternum and ventrite 1 distinctly depressed in middle and pubescent in male. Hind femur with long hairs ventrally between base and tooth in male. Taiwan.

B. morimotoi

2(1): Antennae with 2nd funicle segment shorter than 1st. Mesosternum sometimes weakly depressed, but not evidently concave. Metasternum and ventrite 1 weakly depressed in middle and at least with scales on ventrite 1 in male. Hind femur without long hairs ventrally between base and tooth in male.

3(4): Lenticular area between eyes very narrow, less than apical width of antennal scape. Mesosternum depressed. Elytra with humeri produced anteriorly. Sri Lanka.

B. ceylonensis

4(3): Lenticular area between eyes evident, wider than apical width of antennal scape. Mesosternum not depressed. Elytra with humeri not produced anteriorly. Australia: Queensland. B. exilis

\section{Brimoides sp.1.}

Small species (2.2 mm), similar to B. exilis, but mesosternum weakly depressed.

Specimen examined. 1 specimen, East Malaysia, Sabah, Poring, 15-18.viii.1981, $(K$. Morimoto).

\section{Brimoides sp.2.}

Largest species (3.4 mm in length) among congeners. Pronotum and elytra with indefinite scale pattern.

Specimen examined. 1 specimen, Philippines, Bisling, Surigao del Sur, 1-4.ix.1979, (K. Morimoto).

Abrimoides Kojima \& Lyal, gen. nov.

Type species: Metetra esakii Morimoto, 1958: 16. 

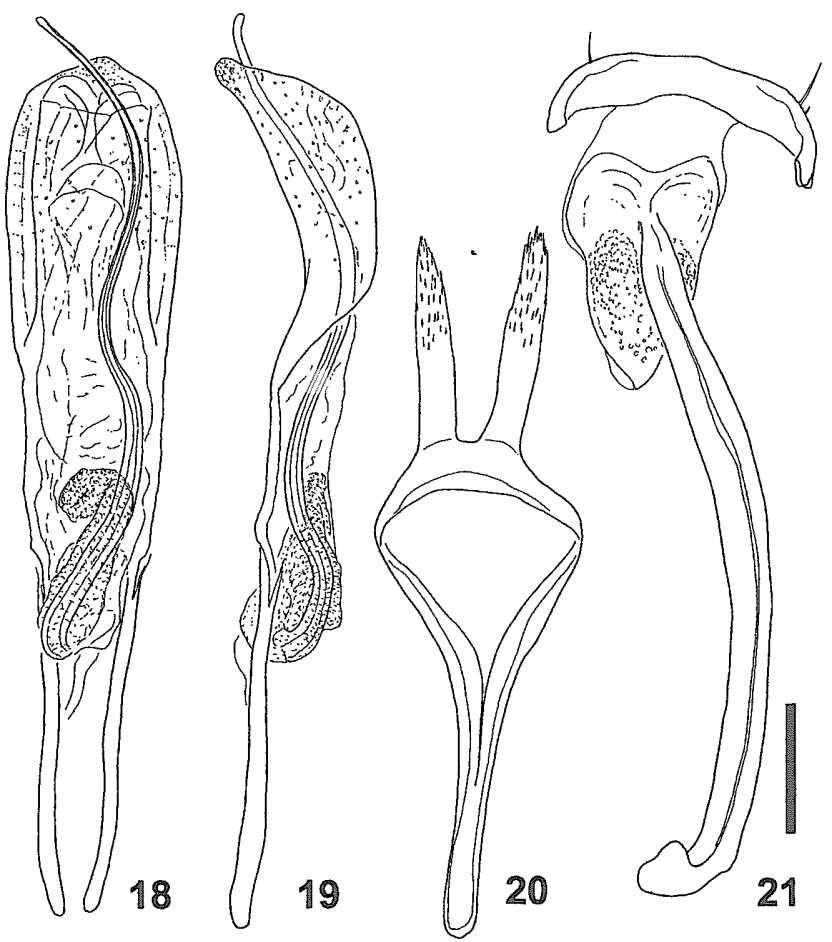

Figs. 18-21. Male genitalia of Abrimoides esakii (Morimoto). - 18, aedeagus, dorsal; 19, aedeagus lateral; 20, tegmen; 21 sternite 8 and spiculum gastrale.

Very similar to Brimoides, but differs in the following features: Integument glossy, with scaly and hairy patterns; scales dorsally generally elongate, ventrally and laterally more rounded; antennae inserted in distal half of rostrum, before middle; scape nearly as long as funicle; prothorax with basal projection in middle, the projection subtruncate at apex, not obscuring scutellum; dorsum of prothorax with median keel on basal 2/3; elytra conjointly rounded at apices, with stria 10 diminished beyond position of ventrite 4; pectoral canal present (Fig. 14), lateral carinae extending between anterior margin of prosternum and procoxae, with short parallel carinae behind coxae; mesosternum canaliculate, but canal lacking lateral carinae, canal terminated by cup formed by anterior edge of metasternum.

Distribution. Japan, Taiwan.

Comments. As mentioned in the introduction, the type species was described in the Lobotracheline genus Metetra, but the scutellar lobe of the pronotum is not developed to cover the scutellum, the insides of the femora are not excavated to receive the tibiae, the tibial unci are directed forwards not ventrad, and the tarsal claws are simple and free. These characters preclude this species from belonging to Metetra or the Lobotrachelini. 

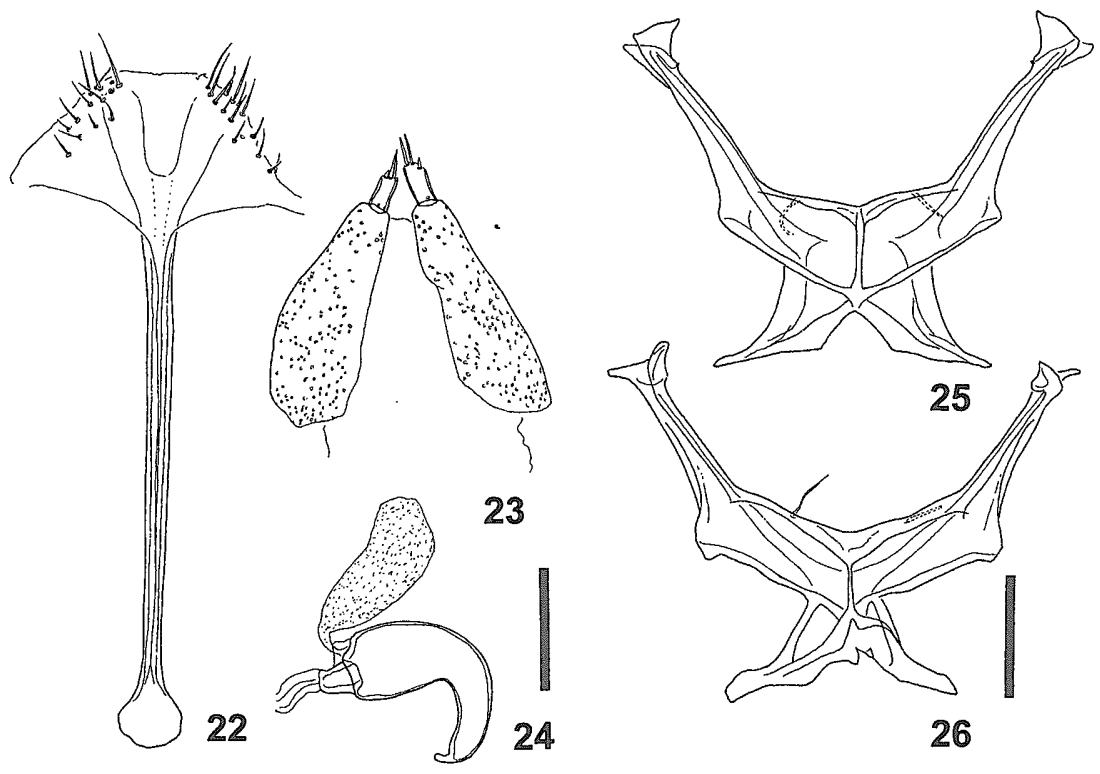

Figs. 22-26. Female genitalia and metendosternites of Abrimoides and Brimoides spp., 22, sternite 8 and apodeme; 23 , hemisternite of ovipositor; 24 , spermatheca; 25,26 , metendosternite. -24-26. Abrimoides esakii (Morimoto); 25, Brimoides morimotoi sp. nov.

Abrimoides esakii (Morimoto), comb. nov.

(Figs. 7-8, 14, 18-24, 26).

Metetra esakii Morimoto, 1958: 16 (fig. 1 for dorsal and lateral view of body \& fig. 2 for aedeagus; type locality: Satamisaki, Kagoshima Pref., Japan). - Morimoto, 1984: 319 (Japan: Kyushu, Ryukyus).

As described by Morimoto (1958) except for the following points: Prothorax not as long as wide but 1.5 times as wide as long; lateral 2 striae not joined above ventrite 4 but close to each other at that point; ultimate stria diminished beyond level of ventrite 4 . Male and female terminalia as illustrated (Figs. 18-24); endophallus with long sinuate sclerite. Length: $1.8-2.8 \mathrm{~mm}$.

Specimens examined. 57 specimens (including holo- and paratypes) from Japan: Kyushu (Nagasaki: Nakadouri and Hirashima Is.; Kümamoto: Amakusa; Kagoshima: Cape Sata and Shiroyama), Ryukyus (Tokara Is.: Nakanoshima I.; Amami-Ôshima I.; Okinawa-hontô I.; Ishigaki-jima I. and Yonaguni-jima I.) and Taiwan (Taipei Hs.: Yangmingshan, Ilan and Wulai; Wenchuan Hs.: Nanshanchi; Nantou Hs.: Sungkang and Penpuchi; Chiai Hs.: Fenchifu; near Liu Kui: Sha Ping) collected on April to August. 
Distribution. Japan (Kyushu, Ryukyus), Taiwan.

Biology. The weevils are found on Oreocnide pedunculata and Debregeasia edulis (Hadonoki and Yanagiichigo in Japanese) of the family Urticaceae (Matoba, per. comm.).

\section{Systematic position of Brimoides and Abrimoides among the Othippiini}

Among Othippiini, at first appearance these new genera are similar to Othippia Pascoe in having a rhomboidal body with a scaly or hairy pattern, and the rostrum capable of being retracted between the pro- and mesocoxae. However, they are strikingly different in two characters: firstly, the eyes are very close together anteriorly and posteriorly, but separated by a lenticular area on the top of the head in the new genera; this lenticular area is not developed in Othippia. Secondly, the femora do not have a ventral groove to accommodate the tibiae when the legs are folded. The new genera are more similar to Brimoda Pascoe and its allied genus Rimboda Heller, particularly in the characters of the eyes. Interestingly similar eyes structure can see in the genera of Mecopini, but member of this tribe have only 6-segments in the funicle.

\section{Taxonomic notes on the Othippiini}

Thirteen genera are at present placed in the Othippiini (Alonso-Zarazaga \& Lyal, 1999). However, following a preliminary study of the monophyly of the Othippiini the following genera must be removed from the tribe. No apomorphies have yet been identified for the Othippiini.

Annahowdenia Alonso-Zarazaga \& Lyal, 1999. This was recently proposed as a replacement name for Podalia Pascoe. Annahowdenia is closely related to Podeschrus Roelofs and is here transferred to the Menemachini (new placement).

Oebrius Pascoe is very similar to Imathia Pascoe and must be transferred to Curculioninae: Storeini (new placement).

Pycnorhinus Marshall seems to be a member of Baridinae from the structure of ventrites $2-4$, which have broadly curved posterior margins, and is placed in Baridinae incertae sedis.

The following Austromalayan genera, which have a shiny rhomboidal body, must be removed from Conoderinae, but their position is uncertain at present: Brephiope Pascoe, Lissoglena Pascoe, Panigena Pascoe and Pseniclea Pascoe.

As a result, the following genera are retained in this Othippiini: Apiophorus Roelofs, Brimoda Pascoe, Chelothippia Marshall, Egiona Pascoe, Othippia Pascoe, Rimboda Heller, Brimoides gen. nov. and Abrimoides gen. nov. Among them, Apiophorus and Egiona were treated separately by Alonso-Zarazaga \& Lyal (1999). However, Apiophorus was 
synonymized with Egiona by Morimoto (1962). In this study we examined both type species and concur with Morimoto's treat.

The Othippiini is distinguishable from other Conoderinae in having a combination of the following features: canaliculate prosternum bordered by keels (except Rimboda, where prosternum weakly depressed and faintly keeled laterally before coxae); 7 funicular segments; scutellar lobe of pronotum not developed to cover scutellum and mesepimera not ascending upwards between base of pronotum and elytra. Genera assigned to the Othippiini can be separated by the following key. The Othippiini is, however, still lacking any synapomorphy for a tribe, and further study is necessary.

\section{Key to genera}

1(8): Eyes close together anteriorly and posteriorly, but separated by lenticular area on top of head. Femora each without tarsal groove or with very short one, bare keel absent dorsally and ventrally. Rostrum may or may not be capable of being retracted between coxae depending on taxa.

2(7): Prosternum with canal, bordered by well-developed carinae.

3(4): Pectoral canal on prosternum only. Distance between procoxae less than least width of rostrum, thus rostrum does not fit fully between coxae in repose. Hind femora not exceeding apices of elytra. Ventrite 2 a little longer than 3 or 4.

Brimoda Pascoe

4(3): Pectoral canal extends to mesosternum. Distance between coxae as wide as least width of rostrum, thus rostrum fits fully between coxae in repose. Hind femora exceeding elytral apices. Ventrites 2-4 each subequal in length.

5(6): Antennae inserted in basal half of rostrum. Prosternum with lateral carinae bordering pectoral canal reaching middle parts of coxae.

Brimoides gen. nov.

6(5): Antennae inserted in distal half of rostrum. Prosternum with lateral carinae of pectoral canal only between anterior margin of prosternum and procoxae.

Abrimoides gen. nov.

7(2): Prosternum weakly depressed before coxae, not canaliculate, but bordered weakly. Hind femora greatly exceeding elytral apices. Rimboda Heller

8(1): Eyes close together around middle and separate anteriorly and posteriorly. Femora each with tibial groove on anterior margin, more or less with bare keel on dorsally and ventrally, respectively. Rostrum always capable of being retracted between coxae.

9(10): Pygidium exposed. Antennal scrobes running to lower part of rostrum. 
(=Apiophorus Roelofs)

10(9): Pygidium concealed. Antennal scrobes running beneath the base of rostrum.

11(12): Pectoral canal reaching mesosternum, rarely anterior part of metasternum depressed, but inner wall of mesocoxa invisible and rostrum not touching it when retracted. Claws simple. Othippia Pascoe

12(11): Pectoral canal continuing on metasternum, inner wall of mesocoxa visible and rostrum touching it when retracted. Claws appendiculate. Chelothippia Marshall

\section{Biological information}

The biology of the Othippiini is hardly known except for Chelothippia butae Marshall, the larvae of this species being found in living twigs and small branches of Butea frondosa of the family Fabaceae (Gardner, 1938). Adults of Abrimoides esakii were captured on living trees of Oreocnide pedunculata and Debregeasia edulis of the family Urticaceae (Matoba, per. comm.). The larval host of this species is not yet confirmed but they may develop in living twigs and stems. The plant family Urticaceae seems also to serve as host of some species of the Lobotracheline genus Lobotrachelus, although some species are known to use Urena lobata (Malvaceae) and develop in its green stems (Gardner, 1934). It is interesting if both genera Abrimoides (Othippiini) and Lobotrachelus (Lobotrachelini) use Urticaceae as their host, in that if is the case then the superficial morphological resemblance would then be matched in terms of their biology.

\section{Ackmowledgments}

We would like to thank Dr. Katsura Morimoto (ELKU) for his valuable comments on this study and Mr. Isao Matoba (Wakayama Prefectural Museum, Natural History) for his useful information on the collecting record of Abrimoides esakii. HK also thanks Dr. Richard T. Thompson (BMNH) for his kind support during the stay in his museum and Dr. Junichi Yukawa (ELKU) for his continuous encouragement. This study is supported by a Grant-in-Aid from the Ministry of Education, Science, Sports and Culture, Japan (No. 13740491) and a grant from the British Council (to Kojima).

\section{References}

Alonso-Zarazaga, M. A. \& C. H. C. Lyal, 1999. A World Catalogue of Families and Genera of Curculionoidea (Insecta: Coleoptera)(Excepting Scolytidae and Platypodidae). 315 pp. (Entomopraxis, Barcelona) 
Eberhard W. G. \& J. M. Garcia-C., 2000. Ritual jousting by horned Parisoschoenus expositus weevils (Coleoptera, Curculionidae, Baridinae). Psyche, 103 (1-2): 55-84.

Gardner, J. C. M., 1934. Immature stages of Indian Coleoptera (14) (Curculionidae). Indian For. Rec., 20: 48+6pls.

Gardner, J. C. M., 1938. Immature stages of Indian Coleoptera (24, Curculionidae contd.). Indian For. Rec. (N. S.) Entomol., 3(12): 227-261+6pls.

Heller, K. M., 1894. Zygopiden-Studien mit besonderer Berücksichtigung der Gattung Mecopus. Abh. Mus. Dresden, (1892/93), 4(2): 1-48+1 pl.

Heller, K. M. 1894a. Neue Zygopiden, Isorhynchiden und Sympiezopiden nebst ergänzenden Bemerkungen zu bekannten Arten. Tjdschr. Ent., 37: 33-66.

Heller, K. M., 1895. Zygopiden-Studien II, mit besonderer Berücksichtigung der Gattung Copturus. Abh. Mus. Dresden, 1894/95, (11): 1-70+1 pl.

Hespenheide, H. A., 1973. A novel mimicry complex: beetles and flies. J. Entomol. (A), 48 (1): 49-56.

Hustache, A., 1934. Curculionidae: Zygopinae. In Schenkling, S. (ed.), Coleopterorum Catalogus auspiciis et auxilio W. Junk. 136: 1-96.

Lyal. C. H. C., 1986. Observations on zygopine weevil behaviour (Coleoptera: Curculionidae: Zygopinae). J. Nat. Hist., 20: 789-798.

Morimoto, K., 1958. On the tribe Lobotrachelini from Japan (Col., Curculionidae, Zygopinae). Ins. Mats., 22: 15-21.

Morimoto, K., 1962. Provisional checklist of the family Curculionidae of Japan. I. Sci. Bull. Fac. Agr., Kyushu Univ., 19: 183-217.

Morimoto, K., 1984. Curculionidae. In Hayashi, M., K. Morimoto \& S. Kimoto (eds.), Coleoptera of Japan in Color. IV. Hoikusha, Osaka. (In Japanese.)

Pascoe, F. P., 1871a. Catalogue of Zygopinae, a subfamily of Curculionidae, found by $\mathrm{Mr}$ Wallace in the Eastern Archipelago. Ann. Mag. Nat. Hist., (4)7(39): 198-222.

Pascoe, F.P., 1871b. Catalogue of Zygopinae, a subfamily of Curculionidae, found by $\mathrm{Mr}$ Wallace in the Eastern Archipelago. Ann. Mag. Nat. Hist., (4)7(40): 258-266 + pls. XV, XVI.

Pascoe, F. P., 1885. List of the Curculionidae of the Malay Archipelago collected by Dr. Odoardo Beccari, L. M. d'Albertis, and others. Ann. Mus. Civ. Stor. Nat. Genova, 22: $201-332+$ pls. I-III. 